\title{
STUDIES ON WATER QUALITY AND SOME HEAVY METALS IN HYPERSALINE MEDITERRANEAN LAGOON (BARDAWIL LAGOON, EGYPT)
}

\author{
Mohamed H.H. Ali, Mohsen F. Sayed and \\ Mohamed E. Goher \\ 1. National Institute of Oceanography and Fisheries, Cairo, Egypt.
}

Keywords: hypersaline lagoon, Lake Bardawil, physicochemical conditions, heavy metals, nutrient salts.

\begin{abstract}
卫工 he concentrations of some heavy metals in water of Bardawil Lagoon located in East northern Egypt, in relation with some abiotic variables were investigated in this study. The water quality characteristics over the sampling period and the levels of heavy metals from the Lagoon were evaluated from twelve stations covering the whole lagoon area through twelve successive cruises that commenced in January 2004 and ended in December 2004. The Lagoon water quality characteristics were mostly in the normal range for marine habitat and lied under the international permissible levels. The recorded levels of major cations and anions in the water lagoon were higher than the corresponding sea water levels and indicate its higher salinity level than sea water. In addition, the average values of nutrient salts and studied heavy metals (Fe, Mn, Zn, Cu and $\mathrm{Pb}$ ) in the water samples were lorwer than the respective reference values for water. Based on this study, the human health risk for heavy metals in Bardawil Lagoon are still low at present.
\end{abstract}

\section{INTRODUCTION}

Bardawil Lagoon is a shallow hypersaline water body separated from the sea by a long and narrow sand barrier. It varied in its width from $100 \mathrm{~m}$ to $1000 \mathrm{~m}$. Also, it is connected to the Mediterranean Sea by three openings; two of them are man-made "artificial" inlets named "Boughaze I" at the western side and " Boughaze II" at middle side, whilst the third one is natural opening and located at the eastern side at El-Zaranik Protectorate The two artificial inlets are opened periodically by dredging. During Israeli occupation to Sinai in 1967, both inlets were closed by 
1970. Thus, the salinity of the lagoon undergone drastic increase that reached up to $120 \%$ (Pisanty, 1980). The inlets were reopened from 1972 till 1978, then salinity decreased from $38.5 \%$ at Boughaze area to $74.5 \%$ at the most western part of the lagoon. Bardawil Lagoon is the source of an important local fishery, producing over 2,500 tonnes annually; mostly of the high-value saltwater fishes such as Sparus auratus and Mugil sp., and employing about 3,000 fishermen. Fishing is suspended between January and May, in order to allow fish stocks to recuperate.

The importance of Bardawil as a stop-over and staging site has not been investigated thoroughly, but there are indications that at least a portion of the massive numbers of migrants passing through Zaranik protected area, particularly in autumn, utilize some of the habitats available at the lake. Diversity of breeding species is very low. However, two of the six species known to breed in the immediate vicinity of the lake namely; Sterna albifrons and Charadrius alexandrinus, occur in internationally important numbers.

Moreover, it is of moderate importance for wintering water-birds e.g. Phalacrocorax carbo and Phoenicopterus ruber.

Inspite of the great importance of Bardawil Lagoon, monitoring studies are still scarce. These few studies dealt with different environmental aspects of the lagoon including geological aspects, hydrological regime, physicochemical properties, bacterial indices, phytoplankton composition, benthic invertebrates and fishery status (Levy, 1971; Ben-Tuvia, 1975 \& 1979; Krumgalz et al., 1981; Fouda and Wanas, 1987; Siliem 1988 \& 1989 a \& b; Shehata, 1989; Lotfy, 2003 a, b \& c, Ameran, 2004; El-Shabrawy, 2006; Sabae, 2006 Farahat, 2006).

Not only great efforts are needed for maintenance of the purity and healthy of this lagoon, but as well additional information is needed to provide a data base for optimal fisheries and water quality status that help the proper management of the lagoon.

The main objectives of this research are: (1) to determine the water quality characteristics of Bardawil Lagoon and (2) to determine the levels of some heavy metals (Fe, $\mathrm{Mn}, \mathrm{Zn}, \mathrm{Cu}$ and $\mathrm{Pb}$ ) because of their health implications to human populations consuming fishes from the lagoon. 


\section{MATERIAL AND METHODS}

Study area

Bardawil Lagoon is one of the largest lagoons in Egypt, situated in the North of Sinai Peninsula between longitudes $32^{\circ} 40^{`}$ and $33^{0} 30^{`} \mathrm{E}$ and latitudes $31^{0} 03^{\backslash}$ and $31^{0} 14^{`} \mathrm{~N}$. Desert and sand dunes border the southern side of the lagoon. The length of lagoon is about $90 \mathrm{~km}$ along the northern coast of Sinai between El-Qantara and El-Arish Cities. Its maximum width is about $20 \mathrm{~km}$. The water depth in the lagoon ranges from few centimeters near-shore area to about $2.5 \mathrm{~m}$ in the central part and the mean depth is about $1.45 \mathrm{~m}$.

\section{Collection of samples}

Twelve stations were selected to covered the whole area of the lagoon. Water samples were taken monthly from January 2004 till December 2004, using Ruttner Water Sampler bottle with capacity of 2L. For heavy metals determination, the samples were collected seasonally in clean plastic bottles and acidified with few drops of conc. nitric acid.

\section{Procedure:}

The methods discussed in the American Public Health Association (APHA, 1992) were used for determination of the abiotic parameters unless noted. The $\mathrm{pH}$ values were measured during the time of sampling using $\mathrm{pH}$ meter model (Jenway 3150) after calibration with buffer solutions of $\mathrm{pH} 4$ and 10 . Dissolved oxygen was estimated by using the modified Winkler method. BOD was determined by using 5 days method. COD was carried out using potassium permanganate method. Water alkalinity was determined immediately after collection of the samples, using phenolphthalein and methyl orange indicators. Ammonia was determined by phenate method. Nitrite was determined using colorimetric method while nitrate was determined by reduction method as described by Mullin and Riley (1956). Orthophosphate and total phosphorus were determined by using stannous chloride and acid molybdate method. Silicate was determined by using molybdate method. For heavy metals, water samples were digested by adding $10 \mathrm{ml}$ nitric acid to $500 \mathrm{ml}$ of mixed sample in a beaker. Slow boiling and evaporation on a hot plate were done to reach the lowest volume. Beaker walls were washed carefully with distilled water then the digested samples were transferred to a $100 \mathrm{ml}$ volumetric flask and completed to the mark. 


\section{pH Values}

\section{RESULTS AND DISCUSSION}

The values of $\mathrm{pH}$ showed slight variation among different stations and months which fluctuated between minimum value of 7.95 recorded at station III during October and the maximum of 8.8 recorded at station XI during March. The $\mathrm{pH}$ values increased slightly during spring which can be attributed to photosynthetic activity causing reduction of $\mathrm{CO}_{2}$ amount in water (El-Wakeel and Whaby, 1970).

\section{Dissolved oxygen, biological and chemical oxygen demand}

Water of Bardawil Lagoon is well oxygenated during different time intervals. The minimum DO value of $4.8 \mathrm{mg} / \mathrm{l}$ was recorded at station VI during July which was attributed to elevation of temperature that led to decrease the solubility of oxygen gas (Rai, 2000), while the maximum of 10.2 $\mathrm{mg} / \mathrm{l}$ was recorded at station I during January, due to decreasing of temperature and to the prevailing winds which permit to increase the solubility of atmospheric oxygen (Romairo et al., 1979) (Table 3). On the other hand, Bardawil Lagoon has low values of both biological and chemical oxygen demand except at the El-Telul area, which suffered from various pollutants resulting from the tailings of fishermen. Their values fluctuated between 1.2-6.5 and 2.1-9.2 mg/l respectively (Table 3).

The obtained data for oxygen properties (DO, BOD and COD) showed that dissolved oxygen (DO) values were almost higher than the corresponding BOD and COD values, indicating good water quality (Fig. 2 ), also the biological oxygen consumption ratios (BOC) fluctuated between 20 to $68 \%$, revealing good healthy water indication (Wetzel, 1983).

\section{Major Anions}

Carbonate in Bardawil Lagoon is almost depleted especially during autumn and winter as a consequence of its precipitation as $\mathrm{CaCO}_{3}$ onto the overlying sediment and conversion to bicarbonate, then increased gradually during spring and summer and reached its maximum value of $40 \mathrm{mg} / \mathrm{l}$ due to increase of the amount of dissolved carbon dioxide which is converted to carbonate in the water environment (Spotte, 1979).

Bicarbonate values fluctuated between 120 - $220 \mathrm{mg} / \mathrm{l}$ (Table 3), showing an obvious decrease during spring due to utilization of dissolved carbon dioxide that resulted from converting calcium bicarbonate to calcium carbonate (Aboul-Kassim, 1987). Then they showed a remarkable increase during summer which may be attributed to high rate of evaporation that increased salt content (Siliem, 1988b) 
The chlorosity of Bardawil Lagoon is governed mainly by two factors; the first is climatic condition especially the high evaporation rate, and the second is the intrusion of seawater through the inlets. So, the chlorosity increased from inlets towards southern and western areas. The lowest chloride values were always recorded at Boughazes I and II area with a minimum value of $21.0 \mathrm{~g} / \mathrm{l}$, while the highest values always recorded at the most western part of the lagoon, with a maximum value of $46 \mathrm{~g} / \mathrm{l}$ (Table 3 and Fig. 3). The distribution pattern of sulphate showed a closely similar trend as chloride, however its values fluctuated between 2.9 - $6.6 \mathrm{~g} / \mathrm{l}$, showing the lowest values at Boughazes areas and the maximum values at the most western area (Table 3 and Fig. 4).

\section{Major Cations}

Major cations showed their highest contents during hot months and at the most western part of the lagoon at Rabaa, which is mainly attributed to high evaporation rate in addition to the fact that this area is far from the Boughaze inlets. The lowest values were recorded at Boughaze inlets during cold months as a result of sea water intrusion which dilutes the lagoon water (Table 3 and Fig. 5). As a consequence, minimum calcium and magnesium values (441 mg/l and $1.53 \mathrm{~g} / \mathrm{l}$ ) were recorded during March at Boughazes I and II respectively, while maximum values $(1200 \mathrm{mg} / \mathrm{l}$ and $3.11 \mathrm{~g} / \mathrm{l})$ were recorded during August at Station XII (Rabaa region). It is clear that, magnesium contents in Bardawil Lagoon showed high values that exceed 3-5 times the calcium contents, due to the fact that magnesium salts are much more soluble than their calcium counterparts. As a result, carbonates of hard waters are usually $>95 \% \mathrm{CaCO}_{3}$ under ordinary $\mathrm{CO}_{2}$ pressure. $\mathrm{MgCO}_{3}$ and $\mathrm{Mg}(\mathrm{OH})_{2}$ precipitate significantly only at high $\mathrm{pH}$ values under most natural conditions. Consequently, the concentrations of magnesium are extremely high in saline basins (Wetzel \& Otsuki, 1974). More or less, sodium and potassium showed the same behavior, where their minimum values (11.7 g/l and $381 \mathrm{mg} / \mathrm{l})$ were recorded at Boughazes I and II respectively, while the highest values ( $25.5 \mathrm{~g} / \mathrm{l}$ and $1032 \mathrm{mg} / \mathrm{l})$ were recorded at Station XII (Rabba region) during August, respectively (Table 3 and Fig. 6).

\section{Nutrient salts}

The present study showed that, nitrites were depleted completely in some stations during the study periods. The annual average value of nitrite was $4.5 \mu \mathrm{g} / \mathrm{l}$, while the highest value $(19.2 \mu \mathrm{g} / \mathrm{l})$ was recorded at station I during winter (Table 3 ). Nitrate showed its minimum value (13 
$\mu \mathrm{g} / \mathrm{l})$ during November at station XII, while the maximum value $(89 \mu \mathrm{g} / \mathrm{l})$ was recorded during January at Boughaze I area. It is clear that, the nitrate concentration increased during spring and winter, which was mainly attributed to the oxidation of ammonia yielding nitrate especially in abundant oxygen and phytoplankton during spring according to the following equations:

$$
\begin{aligned}
& \mathrm{NH}_{4}^{+}+1 \frac{1 / 2}{\mathrm{O}_{2}} \longrightarrow \mathrm{NO}_{2}^{-}+2 \mathrm{H}^{+}+\mathrm{H}_{2} \mathrm{O} \\
& \mathrm{NO}_{2}^{-}+1 / 2 \mathrm{O}_{2} \longrightarrow \mathrm{NO}_{3}^{-}
\end{aligned}
$$

Moreover, the nitrification processes by Nitrosomonas bacteria are responsible for adding nitrate to the water under control of the dissolved oxygen, that is supported by findings of Cooper (1990) and Nixon (1995). The biological reduction of nitrate during autumn is attributed to the dentrifying bacterial action. Ammonia contents in Bardawil Lagoon showed a homogeneous distribution with narrow horizontal fluctuations except station I which suffers from different pollutants. The maximum ammonia value of $138 \mu \mathrm{g} / \mathrm{l}$ was recorded at station I during September, while the minimum value of $9 \mu \mathrm{g} / \mathrm{l}$ was recorded at station XI during February (Table 3 and Fig. 7).

The orthophosphate contents in Bardawil Lagoon showed relative increase during spring and summer more than in other seasons The maximum orthophosphate value of $90 \mu \mathrm{g} / \mathrm{l}$ was recorded at station IX during April, while the minimum value of $10 \mu \mathrm{g} / \mathrm{l}$ was recorded at station III during December (Table 3 and Fig. 8). The reactive silicate contents in Bardawil Lagoon increased during hot months than the other months; the maximum silicate value of $3.08 \mathrm{mg} / \mathrm{l}$ was recorded at station VIII during August, while the minimum value of $0.3 \mathrm{mg} / \mathrm{l}$ was recorded at stations III, VI and XI during March (Table 3). It is obvious that the distribution pattern of silicate in the lagoon varied in the narrow range in most cases that was attributed to the equilibrium between the deposition of silicate and production of biogenic silica from diatoms, which caused preservation in silica content distribution (Verschuren et al., 1998). Moreover, the uptake of dissolved silica by the aquatic microorganism especially diatoms, flagellate microalgae, macrophytes and zoobenthos causing silica preservation (Cole, 1979).

On comparison, the nutrient salts distribution in Bardawil Lagoon during last two decades, a homogeneous conservation trend was shown in the Table (2).The values of nitrite and nitrate fluctuated in a narrow range in most studies except for Shabana (1999) who reported an obvious decrease of both nitrite and nitrate contents, while ammonia content 
showed a relative increase by time reaching 16- 41, 25 - 115 and 138 $\mu \mathrm{g} / \mathrm{l}$ as recorded by Siliem (1989b), Shabana (1999) and during 2004 (present data).

Siliem (1989b) showed an abrupt increase of orthophosphate concentration that reached $235 \mu \mathrm{g} / \mathrm{l}$, followed by an obvious sharp decrease during 1997 reaching $25.3 \mu \mathrm{g} / \mathrm{l}$ (Shabana 1999), and increased again during 2004 reaching about $90 \mu \mathrm{g} / \mathrm{l}$ at El-Boughaze area with an annual average of $35 \mu \mathrm{g} / \mathrm{l}$ in the lagoon (present data). Consequently, N/P ration ranged from $15: 1$ to $5: 1$ during 1986 then decreased in the ranges of $5: 1$ to $2.5: 1$ during 2004 .

During 1960's Ben-Tuvia (1975) reported that, Bardawil Lagoon was classified as an oligotrophic lagoon, with low production associated with low nitrogen and phosphorus contents. Nowadays, in light of the recent data, Seechi depth reached $2.0 \mathrm{~m}$ (Abdel-Satar, 2005), chlorophyll$a$ concentration reached to about $0.9 \mu \mathrm{g} / \mathrm{l}$ (Toulibah et al., 2002) and phosphorus concentration about $35 \mu \mathrm{g} / \mathrm{l}$ (present data).So, the trophic state of Bardawil Lagoon became mesotrophic according to classification of Carlson (1977).

\section{Heavy Metals}

In general, the heavy metals contents in Bardawil Lagoon showed their maximal values at El-Telul area which is the main fishery landing site which receives the tailings of the anglers' boats and is considered the main pollution point in the lagoon. On the other hand, the lowest values mainly recorded at station III (Zaranik area).

The iron values in the lagoon fluctuated in narrow range with obvious increase during summer and spring more than during autumn and winter. High evaporation rate during summer may be regarded as the main reason for increasing of iron, beside the high temperature which decreases the assimilation rate of $\mathrm{Fe}$ by aquatic organisms especially macrophytes (Berg et al., 1995). The highest value of $790 \mu \mathrm{g} / \mathrm{l}$ was recorded during summer at station I, while the minimum value of 200 $\mu \mathrm{g} / \mathrm{l}$ was recorded during autumn at station XI (Fig. 9). On the other hand, manganese values showed an increased trend during hot seasons than cold seasons, which was mainly attributed to the mobilization of manganese from the sediment to the overlaying water due to the decomposition of organic debris by microbial activity (Sung and Morgan, 1981). Its values fluctuated between highest value of $80 \mu \mathrm{g} / \mathrm{l}$ recorded during spring at station I, and the lowest value of $17 \mu \mathrm{g} / \mathrm{l}$ recorded during winter at station VII. 
Zinc showed a similar trend as Fe and $\mathrm{Mn}$, since its highest value $(480 \mu \mathrm{g} / \mathrm{l})$ was recorded during spring at station I, and the minimum value $(95 \mu \mathrm{g} / \mathrm{l})$ was recorded during winter at station III (Fig 9).

On contrast to the results of Fe, Mn and $\mathrm{Zn}$, the levels of copper showed an increase during autumn and winter more than during spring and summer, which was mainly attributed to the precipitation of copper to the sediment as CuS under elevation of temperature (Hutchinson, 1957). The highest value of $25 \mu \mathrm{g} / \mathrm{l}$ was recorded during winter at station I, while the minimum value of $6 \mu \mathrm{g} / \mathrm{l}$ was recorded during spring at station III (Fig. 9).

The obtained results of lead showed slight increase during spring and summer more than that recorded during autumn and winter, which is mainly attributed to the elevation of temperature, that enhanced the mobilization of lead from the sediment, and its liberation to the overlaying water (Berg et al., 1995). The highest value of $53 \mu \mathrm{g} / \mathrm{l}$ was recorded during summer at station I, while the minimum value of $9 \mu \mathrm{g} / \mathrm{l}$ was recorded during winter at station III (Fig 9).

The present study showed that, the obtained results of heavy metals levels are below the standard permissible values cited by World Health Organization (WHO) and European Economic Community (EEC) (WHO 1992). The annual mean values of $\mathrm{Fe}, \mathrm{Mn}, \mathrm{Zn}, \mathrm{Cu}$ and $\mathrm{Pb}$ in the present study $(444,40,166,11$ and $16 \mu \mathrm{g} / \mathrm{l})$ are lower than the corresponding permissible limits $(500,50,5000,50$ and $50 \mu \mathrm{g} / \mathrm{l})$ for the same metals respectively. It is worthy to note that, in spite of the above mentioned levels of heavy metals are still low in Bardawil Lagoon but the probability of the accumulation of these metals in different fish organs are still present.

\section{REFERENCES}

Abdel-Satar, A.M. (2005). On the water quality of Lake Bardawil, Egypt. J. Egypt. Acad. Soc. Environ. Develop., Environmental Studies, 61: $79-73$.

Aboul-Kassim, T.A. (1987). Cycles of carbon, nitrogen and phosphorus in the marine environmental in Alexandria region. M.Sc. Thesis. Fac. Sci. Alex.Univ., 233pp. 
Ameran, M.A. (2004). Studies on the Crustacean fishery in Bardawil Lagoon. Ph.D. Thesis, Fac. Environ. Agr. Sci. El-Arish, Suez Canal Univ.,228pp.

American Public Health Association (APHA) (1992). Standard methods of the examination of water and waste water. $17^{\text {th }}$ edition, AWWA, WPCF, 1015pp.

Ben-Tuvia, A. (1975). Comparison of the fish fauna in the Bardawil Lagoon and the Bitter Lakes. Rapp. Comm. int. Mer Médit., 233: $125-126$.

Ben-Tuvia, A. (1979). Studies of the population and fisheries of Sparus aurata in the Bardawil Lagoon, Eastern Mediterranean. Inv. Pesq., 431: $43-67$.

Berg, H.; Kiibus, M. and Kautsky, N. (1995). Heavy Metals in Tropical Lake Kariba, Zimbabwe. Wat., Air, and Soil Poll., 83 (3/4): 237252

Carlson, R.E. (1977). A trophic state index for lakes. Limnology and Oceanography., 22:361-369.

Cole, G.A. (1979). Text book of limnology. $2^{\text {nd }}$ Edition, St. Louis, Toronto, London, C.V. Mosby Company

Cooper, A.B. (1990). Nitrate depletion in the riparian zone and stream channel of a small headwater catchment. Hydrobiol., 202: 13-26.

El-Shabrawy, G.M. (2006). Ecological study on the zooplankton community in Bardawil Lagoon, Egypt. J. of Thalassia Salentina, 29: 3-19.

El-Wakeel, S. K. and Wahby, S. D. (1970). Hydrography and chemistry of Lake Manzalah, Egypt, Arch. Hydrobiol., 67: 173- 200. 
Farahat, H.F. (2006) sedimentary processes act on Bardawil Lagoon, North Sinai, Egypt. M.Sc. Thesis, Fac. Sci. Banah University, 209pp.

Fouda, M.A. and Wanas, M.K. (1987). On the benthic biota of Bardawil Lagoon on the Mediterranean coast of Sinai, Egypt. Proceedings of Zoological Socirty, A.R.E., 14: $103-115$.

Hutchinson, G.E. (1957). A treatise on limnology. 1. Geography, Physics and Chemistry. John Wiley and sons,. New York, 1015 pp.

Krumgalz, B.S.; Horunung, H. and Oren, O.H. (1980). The study of a natural hypersaline lagoon in a desert area Bardawil Lagoon in Northern Sinai. Est. and Coast. Mar. Sci., 10: 403 - 415.

Levy, Y. (1971). Anomalies of $\mathrm{Ca}^{+2}$ and $\mathrm{SO}_{4}{ }^{-2}$ in Bardawil Lagoon Northern Sinai. Limn. \& Oceanog., 166: 983 - 987.

Lotfy, I.M.H. (2003a). Mineralogical and geochemical studies on four recent molluscan shells from Hypersalline Bardawil lagoon sediments, Egypt. J. Egypt Acad. Soc. Environ. Develop., 42: 199- 218.

Lotfy, I.M.H. (2003b). Organic matter, carbonates and trace metals distribution in recent sediments of Bardawil lagoon, Egypt., J. Egypt Acad. Soc. Environ. Develop., 42: 179- 197.

Lotfy, I.M.H. (2003c). Sedimentlogical studies on recent sediments of Bardawil Lagoon, Egypt., J. Egypt Acad. Soc. Environ. Develop., 42: 157- 178.

Mullin, J. B. and Riely, J. P. (1956). The spectrophotometric determination of nitrate in natural waters, with particular references to see water; Bull. Analytica, chemica ACTA, 12 : 479-480. 
Pisanty, S. (1980). The fishery and management of the hypersaline Lagoon of Bardawil. GFCM Stud. Rev., 58: 35-73.

Rai, A.K. (2000). Limnological characteristics of subtropical Lakes Phewa, Begnas and Rupa in Pokhara Valley, Nepal. Jpn J. Limnol., 1: 33 - 46.

Romairo, R.P.; Boyd, C.E. and Collins, W.J. (1978). Predecting nighttime dissolved oxygen decline in ponds used for Tilapia culture. Trans. m. Fish. Soc., 107: $804-808$.

Sabae, S.Z. (2006). Spatial and temporal variations of saprophytic bacteria, fecal indicators and the nutrient cycle bacteria in Lake Bardawil, Sinai, Egypt. Int. J. of Agric. And Biol., 82: 178 185.

Shabana, E.E. (1999). Limnological studies on Lake Bardawil. M.Sc. Thesis, Fac. Sci., Suez Canal Univ., 135pp.

Shehata, M.B.(1989). Essential fatty acids in the Sparus aurata in Egypt. Ph.D. Thesis, Fac. Sci., Menoufia Univ.

Siliem, T.A.A. (1988a). The chemical conditions in Bardawil Lagoon. IMajor Cations. Bull. Nat. Inst. Oceanogr. \& Fish. ARE., 14: 123 $-140$.

Siliem, T.A.A. (1988b). The chemical conditions in Bardawil Lagoon. IIMajor Anions. Bull. Nat. Inst. Oceanogr. \& Fish. ARE., 14: 141 - 157.

Siliem, T.A.A. (1989a). The chemical conditions in Bardawil Lagoon. IIISome limnological studies. Bull. Nat. Inst. Oceanogr. \& Fish. ARE., 15: 21-33.

Siliem, T.A.A. (1989b). The chemical conditions in Bardawil Lagoon. IV-Nutrient salts. Bull. Nat. Inst. Oceanogr. \& Fish. ARE., 15: $217-228$. 
Spotte, S. (1979). Seawater aquarium: the captive environment. John Wiley and Sons, N. Y., 413 pp.

Sung, W. and Morgan, J.J. (1981). Geochem. Cosmochim. Acta, 45: 2377-238.

Toulibah, H.; Shfik, H.M.; Gab-Allah, M.M. and Taylor, W.D. (2002). Phytoplankton and some abiotic features of El-Bardawil Lake, Sinai Egypt. Afr. J. Aqu. Sci., 27: 97 - 105.

Verschuren, D.; Edgington, D.N.; Kling, H.J. and Johnson, T.C. (1998). Silica depletion in Lake Victoria: Sedimentary signals at offshore stations. J. Great Lakes Res., 241: 118 - 130.

Wetzel, R.G. (1983). Limnology. Saunders College Publishing. $2^{\text {nd }}$ Edition. 767 pp.

Wetzel, R.G. and Otsuki, A. (1974). Allochthonous organic carbon of marl lake. Arch. Hydrobiol., 73: 31 - 56.

WHO (1992). World Health Organization for inorganic constituents of health significance and European Economic Community Standards for parameters Water Quality Standards and Goalls, New York, 1271 pp. 
Table (1): Selected stations, common names and their latitudes and longitude in Bardawil Lagoon

\begin{tabular}{|c|c|c|c|c|c|c|c|}
\hline $\begin{array}{l}\text { St. } \\
\text { No. }\end{array}$ & Name & Latitude & Longitude & $\begin{array}{l}\text { St. } \\
\text { No. }\end{array}$ & Name & Latitude & Longitude \\
\hline 1 & El-Telol & $31^{0} 04^{\backslash} 37^{\prime \prime}$ & $33^{0} 13^{\prime} 36^{\prime \prime}$ & 7 & El-Gals & $31^{0} 11^{\prime} 26^{\prime \prime}$ & $33^{0} 05^{\backslash} 54^{\prime \prime}$ \\
\hline 2 & El-Rodh & $31^{0} 05^{\backslash} 58^{\prime \prime}$ & $33^{0} 15^{\prime} 03^{\prime \prime}$ & 8 & El-Rewak & $31^{0} 03^{\backslash} 50^{\prime \prime}$ & $33^{0} 00^{\prime} 02^{11}$ \\
\hline 3 & El- Zaranik & $31^{0} 07^{\dagger} 03^{\prime \prime}$ & $33^{0} 16^{\prime} 51^{\prime \prime}$ & 9 & $\begin{array}{l}\text { N. El- } \\
\text { Rewak }\end{array}$ & $31^{0} 06^{\prime} 28^{\prime \prime}$ & $32^{0} 56^{\prime} 49^{\prime \prime}$ \\
\hline 4 & Boughaz II & $31^{0} 12^{\backslash} 15^{\prime \prime}$ & $33^{0} 15^{\backslash} 41^{\prime \prime}$ & 10 & Boughaz I & $31^{0} 08^{`} 01^{\prime \prime}$ & $32^{0} 55^{\prime} 47^{\prime \prime}$ \\
\hline 5 & M. El-Telol & $31^{0} 08 \backslash 35^{\prime \prime}$ & $33^{0} 15^{\prime} 40^{\prime \prime}$ & 11 & El-Nasr & $31^{0} 04^{`} 55^{\prime \prime}$ & $32^{0} 49^{\prime} 17^{\prime \prime}$ \\
\hline 6 & Masqut- plis & $31^{0} 11^{\prime} 47^{\prime \prime}$ & $33^{0} 09^{\prime} 20^{\prime \prime}$ & 12 & Rabaa & $31^{0} 03^{\backslash} 24^{\prime \prime}$ & $32^{0} 44^{\backslash} 33^{\prime \prime}$ \\
\hline
\end{tabular}

Table (2): Changes in nutrient salts ( $\mu \mathrm{g} / \mathrm{l})$ in Bardawil Lagoon during different intervals

\begin{tabular}{lcccc}
\hline \multicolumn{1}{c}{ Year } & $\mathbf{1 9 8 5 - 8 6}$ & $\mathbf{1 9 9 7}$ & $\mathbf{2 0 0 0}$ & $\mathbf{2 0 0 4}$ \\
Parameters & (Siliem, 1989) & (Shabana, 1999) & (Abdel-Satar, 2005) & \begin{tabular}{c} 
(present data) \\
\hline \hline Nitrite
\end{tabular} $0^{\text {Nitrate }}$ \\
Ammonia & $35-16$ & $0.2-4.9$ & $2-21$ & $0-19$ \\
Orthophosphate & $3.5-235$ & $2.3-10.1$ & $15-65$ & $13-89$ \\
Silicate & $310-831$ & $25-115$ & $*$ & $9-138$ \\
\hline \hline
\end{tabular}

*: not available 



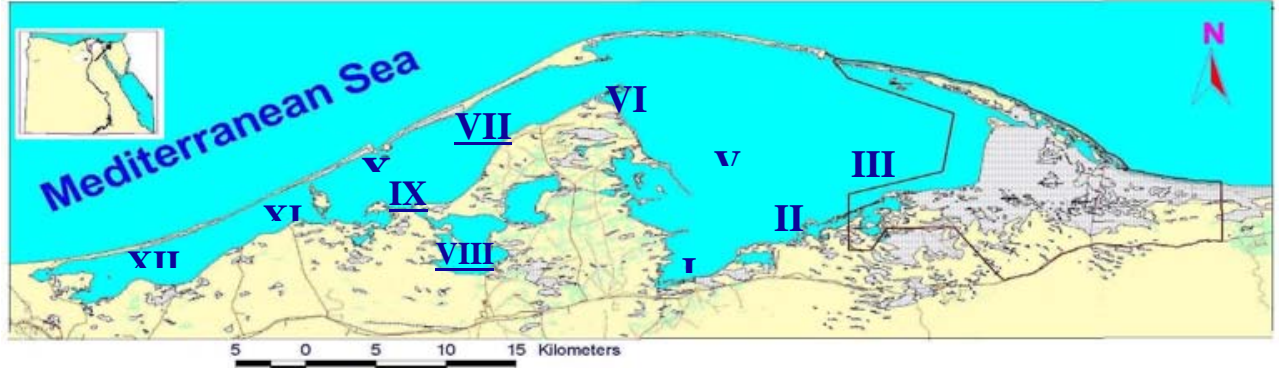

Figure (1): Map showing the location of the Bardawil Lagoon and the selected stations

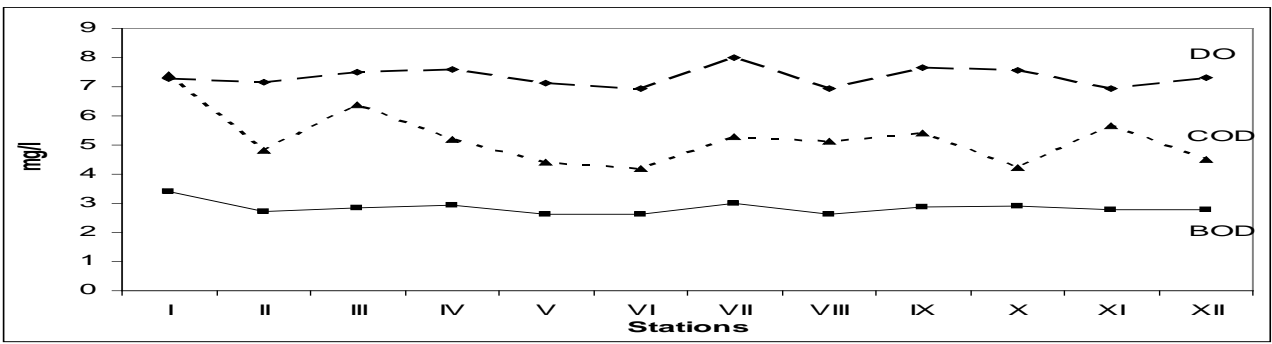

Fig. 2. Average monthly variation of oxygen properties (dissolved oxygen, biological oxygen demand and chemical oxygen demand) in Bardawil Lagoon during 2004.

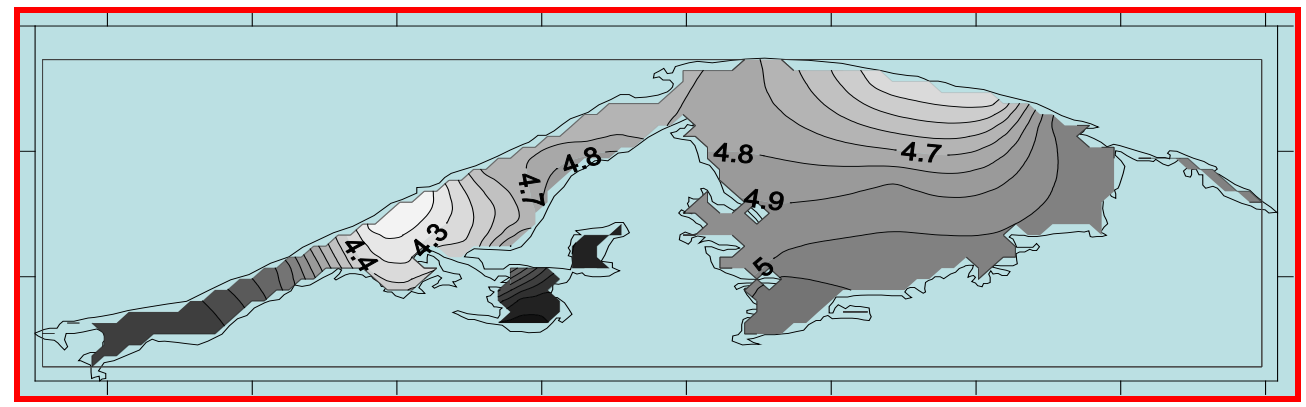

Fig. 3. Average monthly variation of chloride (g/l) in Bardawil Lagoon during 2004. 


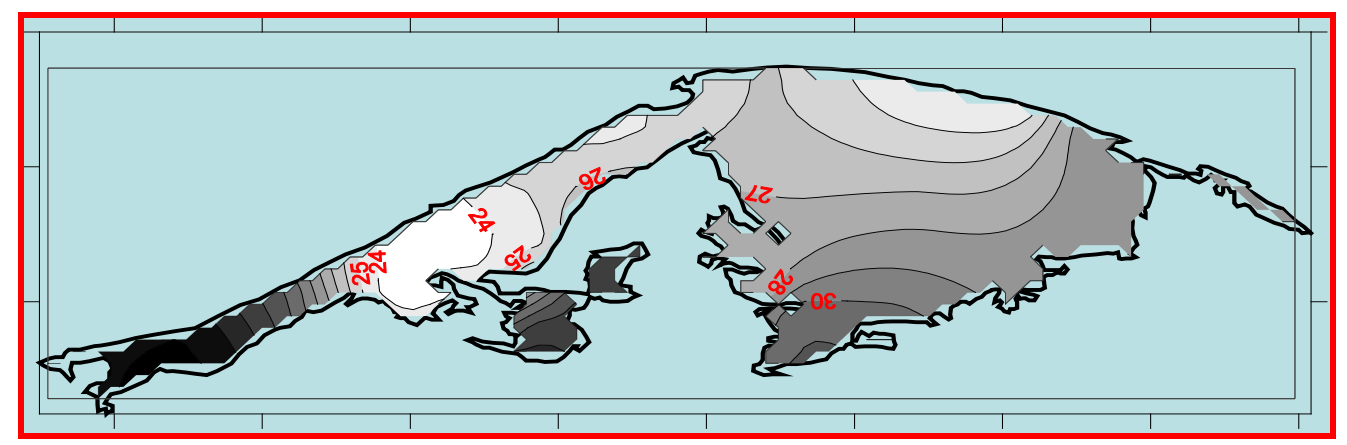

Fig. 4. Average monthly variation of sulphate (g/l) in Bardawil Lagoon during 2004.

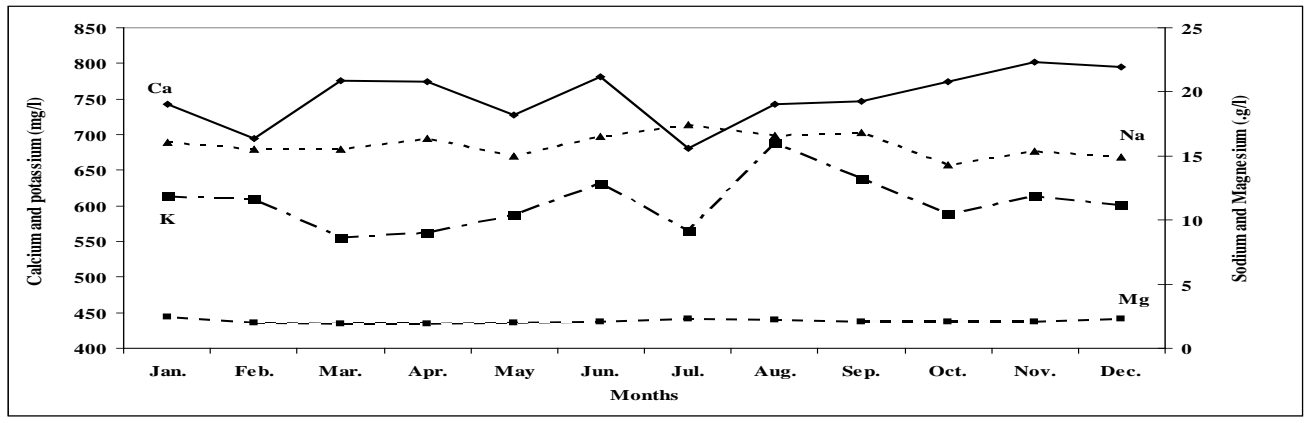

Fig. 5. Average monthly variation of calcium, magnesium, sodium and potassium in Bardawil Lagoon during 2004.

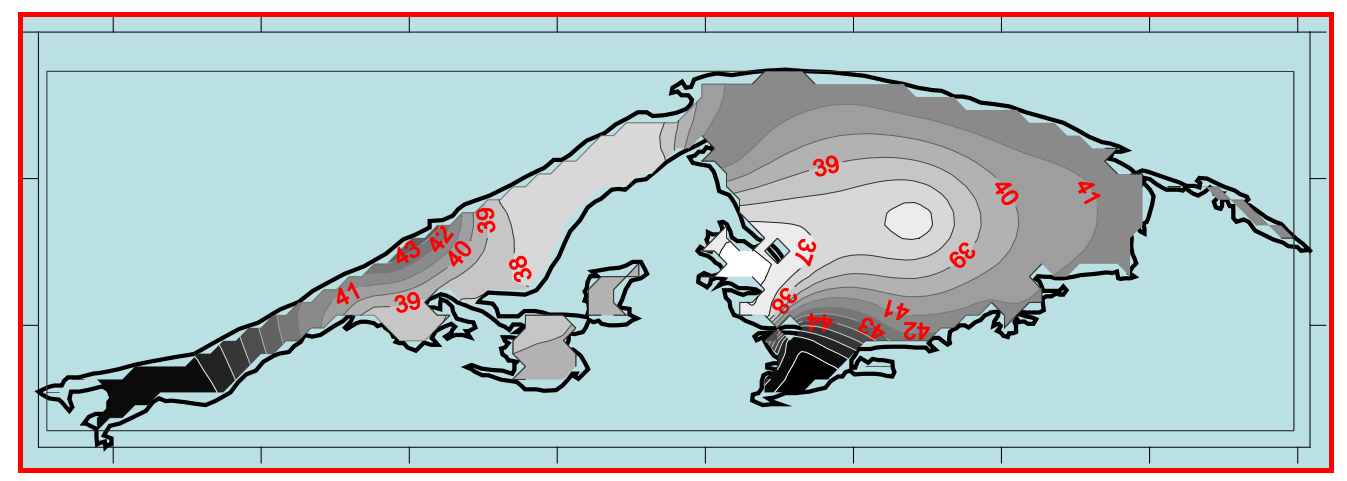

Fig. 6. Average monthly variation of nitrate $(\mu \mathrm{g} / \mathrm{l})$ in Bardawil Lagoon during 2004. 


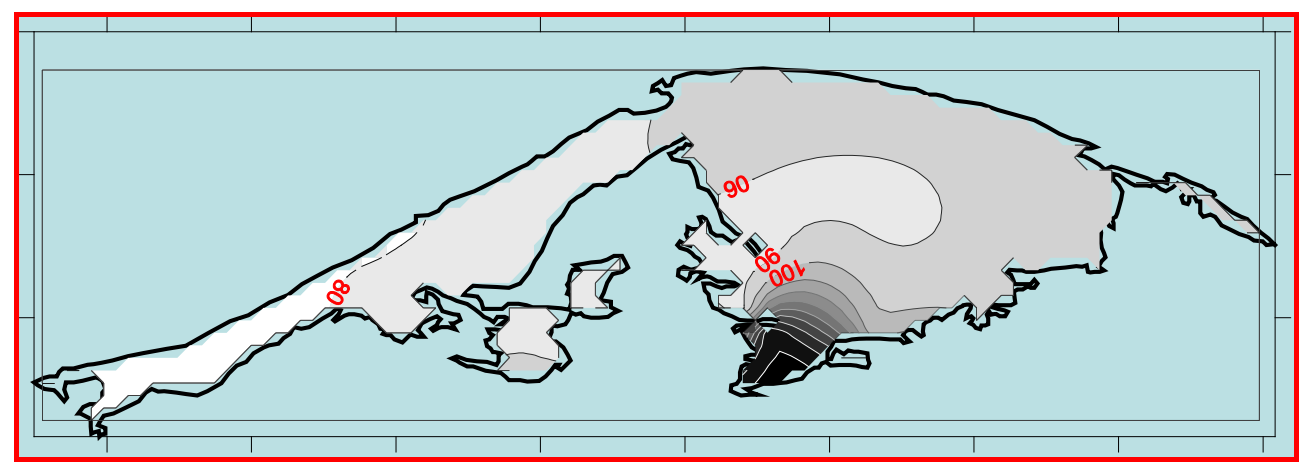

Fig. 7. Average monthly variation of ammonia ( $\mu \mathrm{g} / \mathrm{l})$ in Bardawil Lagoon during 2004.

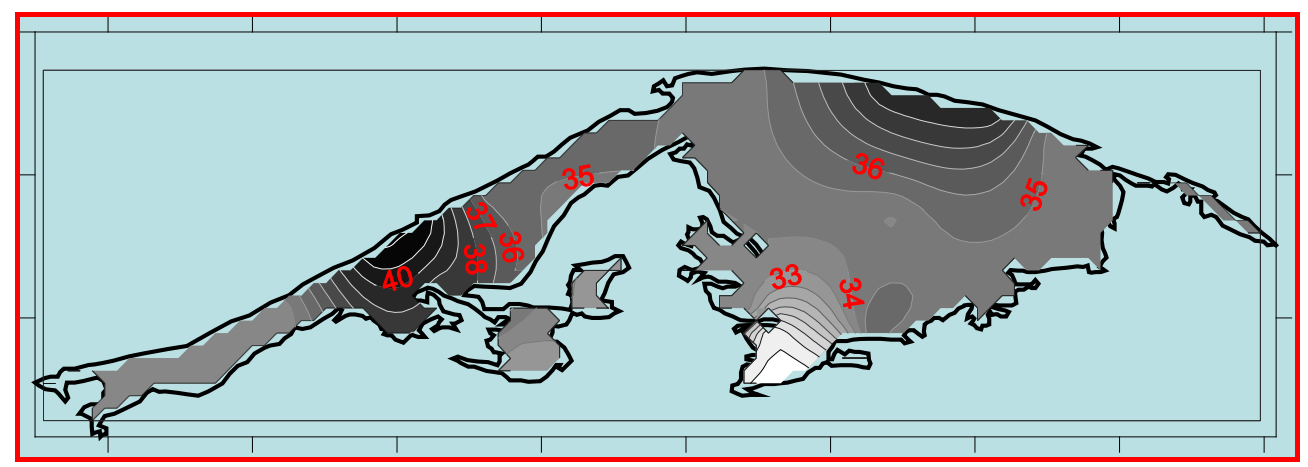

Fig. 8. Average monthly variation of orthophosphate $(\mu \mathrm{g} / \mathrm{l})$ in Bardawil Lagoon during 2004. 

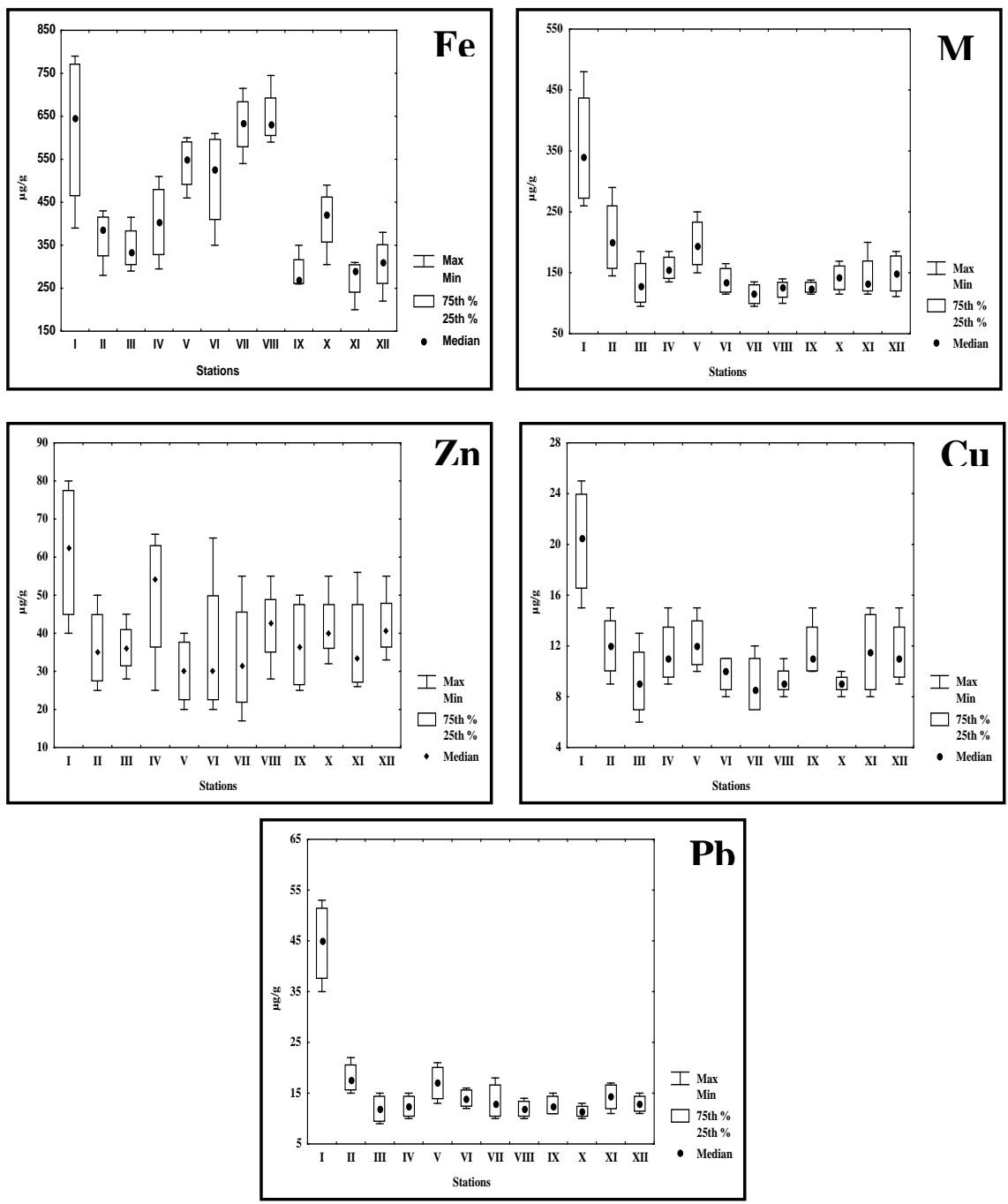

Fig. 9. Seasonal variation of heavy metals (iron, manganese, zinc, copper, and lead) in the Bardawil Lagoon during 2004. 